\title{
The Struggle for Egypt: from Nasser to Tahrir Square
}

Steven Cook's master-class in Egyptian political history since the military coup in 1952 is essential to understanding the political tensions between militarists, Islamists, and democrats which persist up to the present day, finds Matthew Partridge. Essential reading following the election of Mohamed Morsi of the Muslim Brotherhood.

\section{The Struggle for Egypt: From Nasser to Tahrir Square. Steven A. Cook. Oxford University Press. September 2011.}

\section{Find this book:}

Although the first dictator in the region to depart in 2011 was Tunisia's Ben Ali, no country epitomises the changing narrative around the Arab spring more than Egypt. It was Mubarak's resignation in the middle of February that prompted London, Washington, and Paris to break with their previous policies of public silence on the behaviour of incumbent regimes. However, as the protests showed, the final destination of the Egyptian transition remained in the balance for months, with continued military rule, an Islamist coup, or a genuine move to democracy all possible outcomes. This weekend the Arab Spring entered its next chapter however, as Mohamed Morsi of the Muslim Brotherhood was declared Egypt's first democratically elected president.

\section{Steven Cook's The Struggle for Egypt: From Nasser to Tahrir} Square doesn't attempt to make any definite predictions about

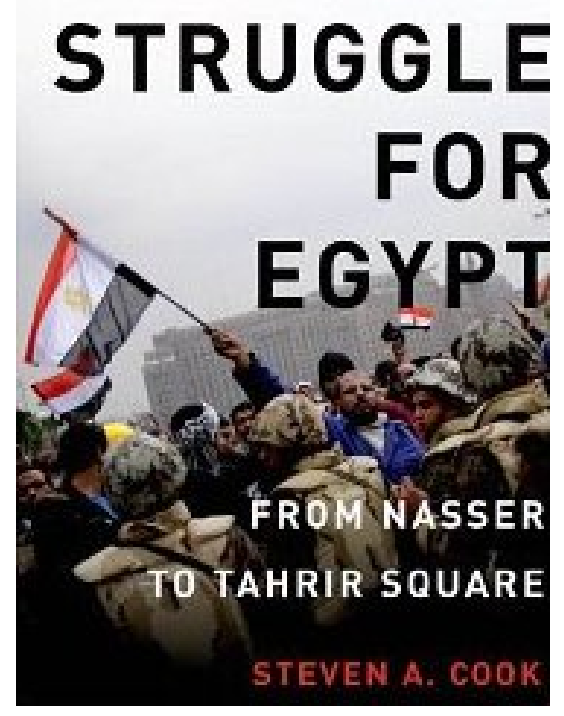
Egypt's political future. Instead, he argues that an understanding of Egyptian political history since the military coup in 1952 is essential to understanding the political tensions between militarists, Islamists and democrats, which have persisted up to amazon the present day. With the exception of the thirty pages of the first chapter, which delivers a potted history of Egyptian politics from the nineteenth century to the "Free Officers" coup d'etat, the focus of the six remaining chapters is strictly on the last fifty-nine years.

Nasser's time in power is covered in Chapters Two and Three, with the former dealing with the political machinations leading up to the nationalisation of the Suez canal and the latter dealing with the 1956 war and its political aftermath. Cook evidently admires aspects of Nasser's rule, praising him for containing Islamism at home, while restoring Egypt's prestige abroad. Cook also largely absolves Nasser of blame for the demise of the United Arab Republic and the disastrous 1967 war. Indeed, it is only at the beginning of Chapter Four, over a hundred pages into The Struggle for Egypt, that Cook admits that, under Nasser, "Egypt remained largely poor, authoritarian and dependant on a global power" [p. 113].

Similarly, Cook believes that by taking part in the 1973 attack on Israel, Nasser's successor, Anwar Sadat, was only following the desires of the vast majority of Egyptians. Indeed, he portrays the Egyptian strongman as a very reluctant participant, "lurching from one explanation of the delay in fighting Israel to another" [p. 130]. Even when Sadat did commit to the offensive, The Struggle for Egypt claims that he did so in a half-hearted fashion, exaggerating both Cairo's objectives and the extent to which Egypt 
was willing to participate in order to get Syrian and Soviet support. The subsequent push for the Sinai, which adhered to Sadat's diplomatic promises rather than the actual battle plan, is explained as an unplanned moment of hubris.

The final third of the book focuses on the final member of the trio, Hosni Mubarak. In contrast to his treatment of Nasser and Sadat, Cook is unambiguously critical of the recently deposed dictator. Chapter Five details the domestic corruption and repression that was a central feature of Mubarak's regime, while the following chapter uses the crash of EgyptAir flight 990 in 1999 as a metaphor for exploring US-Egyptian relations. The final chapter looks at the events leading up the moment when the dictator stepped down, emphasising that by then his regime was so hated that even past recipients of his patronage had turned against him.

Cook is a compelling writer who has a knack for memorable openings and knows how to appeal to both a scholarly audience and the interested general reader. The treatment of the recent political changes in The Struggle for Egypt is a master-class in how popular historians can cover sudden developments while still maintaining a focus on a longer period. Unfortunately, Cook's coverage of Nasser and Sadat comes across as too sympathetic, while his assumption that the authoritarian political structure from 1952 onwards enabled Egypt's leader to avoid a more hard-line foreign policy stance is dubious.

Indeed, the author only briefly mentions the fact that opposition to the 1973 attack on Israel from factions within Sadat's government nearly brought down the regime, and misses an opportunity to contrast Mubarak's encouragement of domestic anti-Iraq war protests with his brutal repression of almost every other form of political expression. While the Tunisian experience suggests that Egyptian parties like the Muslim Brotherhood may derive short-term benefits from the fall of regional dictatorships, much of the blame for their support can be ascribed to the authoritarianism of the last sixty years.

Dr Matthew Partridge completed a PhD in Economic History in 2011 at the London School of Economics. A senior writer for MoneyWeek, he has also written for The Guardian, Times Higher Education and the websites of Prospect and New Statesman. Read more reviews by Matthew.

Related posts:

1. The Egyptian Uprisings: collective effervescence and its shortcomings (8.9)

2. Optimism about the Arab Spring has gone too far (8.4)

3. Book Review: The Strongman: Vladimir Putin and the Struggle for Russia, by Angus Roxburgh (7)

4. From cyberjihad to Habermas: understanding Muslim identity and resistance online (6.9)

5. Book Review: The Performance of Politics: Obama's Victory and the Struggle for Democratic Power by Jeffrey C. Alexander (6.8) 